\title{
Dmitri Kvasov, the Forgotten Eminent Encyclopaedist, and Palaeolimnology
}

\author{
Anto Raukas \\ Institute of Ecology, \\ Tallinn University \\ Uus-Sadama 5, \\ Tallinn 10120, Estonia \\ E-mail: anto.raukas@mail.ee
}

\begin{abstract}
This article aims to present information about Dmitri Kvasov (19321989), one of the most outstanding geographers and palaeolimnologists of the former Soviet Union, who is not so well known in the Western countries and among younger colleagues. Kvasov's political views were unacceptable to the Soviet authorities and it was impossible for him to travel abroad. He regarded the Baltic States as foreign countries and had very close scientific and personal contacts with the Baltic natural scientists. He investigated the history of many large lakes (Ladoga, Onega, Peipsi) and inland seas (Black, Azov, Caspian, White, Baltic), worked out the geographical zonation of the former Soviet Union for palaeogeographical purposes, and organized the publishing of the multi-volume collection of books on the history of lakes in the former Soviet Union.
\end{abstract}

Keywords: evolution of lakes, Holocene, palaeolimnology, Pleistocene, Quaternary palaeogeography

\section{Introduction}

There may be readers, especially in the small European countries, who would be interested in learning some facts about the rivers and lakes in the former Soviet Union. As a whole, there were 9.6 million kilometres of rivers on the territory. The number of lakes was 2.85 million, which without the Caspian Sea covered about $488,000 \mathrm{sq} \mathrm{km}$ or nearly $2.2 \%$ of the territory. Both the largest (the Caspian Sea) and the deepest lakes (Lake Baikal) of our planet are located 
in this part of the world. Ladoga, Onega and Peipsi in the European part of the area are listed among the largest inland bodies of water in Europe. The largest rivers of Russia: the $\mathrm{Ob}(5,410 \mathrm{~km}$ in length together with the Irtysh), the Amur $(4,416 \mathrm{~km})$, the Lena $(4,400 \mathrm{~km})$ and the Yenisei $(4,092 \mathrm{~km})$ rank the fifth, the ninth, the tenth and the thirteenth in length in the world, respectively. However, in terms of water abundance, they occupy even more honourable positions.

To investigate such huge bodies of water an especially talented person was needed, and Dmitri Kvasov (1932-1989) was such a person. Already in his boyhood he used to spend long hours studying the globe and maps. The knowledge acquired in youth later enabled him to correlate events in different oceans and on different continents, and to advance hypotheses about to the causes of ice ages and the formation of planets. He had a brilliant memory which enabled him to feel equally at home with the history of South Africa, the intimate life of Pushkin, or the geography of any country in the world.

Perhaps his talent was inherited because Kvasov was the grandson of the Academician Lev Semyonovich Berg (1876-1950), one of the most famous natural scientists in the history of geography, a long-term president of the Russian Geographical Society, member of the Soviet Academy of Sciences (since 1946, corresponding member since 1928). His mother, Raissa Berg, was a doctor of biology and professor in genetics, a disciple and defender of Academician Nikolai Vavilov against Trofim Lysenko, who destroyed the rapidly developing evolutionary theory and genetics and replaced it with Soviet Michurinist Darwinism. In 1968, Raissa Berg was discharged from all scientific positions and in 1974 she emigrated to the United States, where she worked at different universities. She was a famous Russian dissident, and Iosif Brodsky hid himself in her summer cottage for some time. Therefore it is understandable that Dmitri Kvasov was nevyezdnoi. This was a term applied to people deprived of the right to travel abroad or to meet foreigners even in homeland. But Kvasov was far from obeying the latter order, and foreign researchers were frequent guests in his apartment in Leningrad, full of memories and valuable books which once had belonged to his famous grandfather. Now there is a house museum of Lev Semyonovich.

Dmitri Kvasov was a great supporter of Estonia and Estonians, and even dedicated the 'Ode to Estonia' to the country, which unfortunately remained unpublished. At scientific meetings he openly declared that the Soviet Union would soon collapse and the Baltic States would become independent. He published many joint papers with the Baltic scientists (for example, Kvasov \& Raukas, 1970; Aboltinš et al., 1972; and a number of others). 
Even during expeditions and fieldwork he was always dressed in a suit. This was a subject of mocking and tension among his colleagues. Kvasov took long hiking trips in Karelia and the Caucasus, usually in sparsely populated regions which were difficult to access. He died on one of those journeys far from his home town St. Petersburg. Neither his relatives nor friends had known of his serious heart condition, which made his wandering in the mountains strongly counterindicated. Aware of his serious illness, Kvasov bid defience to death like several well-known Russian geographers and explorers in the past.

\section{Palaeolimnology and the role of Dmitri Kvasov}

Palaeolimnology as the special scientific discipline is studying the past conditions and processes of ancient lakes, the changes of lake size and level, temperature, mineralization and biological productivity. Palaeolimnology investigates the composition of accumulated sediments and the geomorphology and geologic history of ancient lake basins, many of which no longer contain lakes but are dry, flat areas that occasionally may be covered by water.

Together with lakes, palaeolimnology investigates rivers connected to the lakes. For example, the Volga is the longest and most water-abundant river

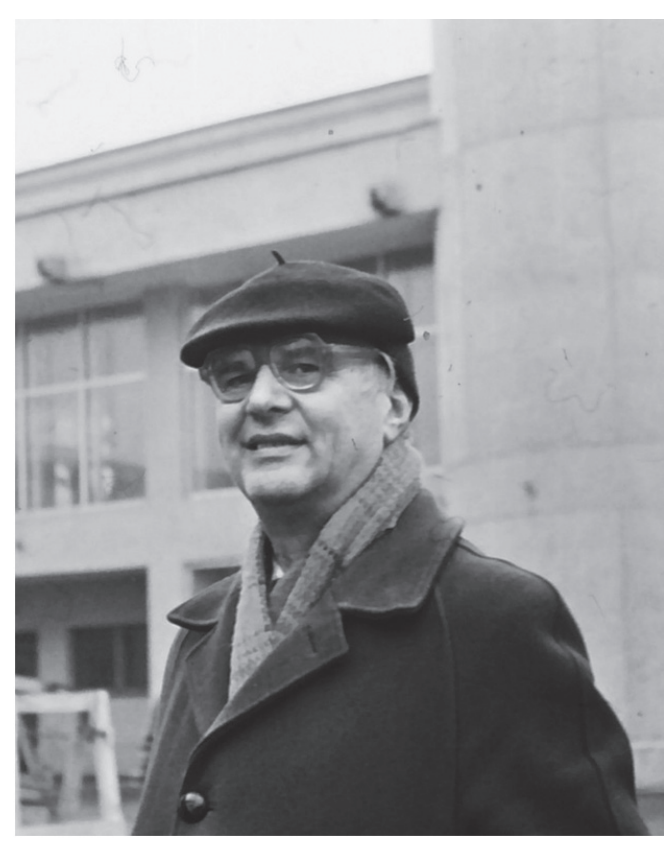

Figure 1. Dimitri Kvasov in 1988.

Photo by Reet Karukäpp. in Europe and one of the best papers of Dmitri Kvasov is dedicated namely to the Late-Quaternary history of this river (Kvasov, 1987a). In that paper he masterfully demonstrated that during the maximal stages of the Weichselian glaciation the Volga was a relatively short river (only about 1,000 km long), which connected the Upper-Volga system of glacial lakes with the Khyalinsk 
basin. About 12,500 years ago the river flowed already in the present direction, but was rather shallow. The discharge seems to have been at its lowest in the Younger Dryas. The river gradually acquired its present dimensions during the Holocene.

The present short review touches upon three principal achievements in Kvasov's scientific research: (1) palaeolimnological zonation of the European part of the former Soviet Union; (2) principally new standpoints with respect to the evolution of lakes in the East-European Plain; and (3) Kvasov as the initiator of the compilation of the multi-volume collection of the history of lakes in the former Soviet Union. Such huge, high-quality work is unknown in other countries of the world.

\section{Palaelimnological zonation of lakes}

In view of many theoretical and practical tasks that scientists face, Kvasov's interest in lake and river formations was entirely understandable. He mentioned the weakest points of lake and river investigations and contributed to the strengthening of working groups. Together with co-authors, he worked out the palaeolimnological zonation of the European part of Russian Federation (Kvasov, 1987b) and the Soviet Union as a whole (Saarse et al., 1987), in the course of which 88 type regions with 103 type sections (Fig. 2) were distinguished and subjected to detailed complex studies. The results obtained by standardized methods and computer processing of data provided a reliable basis for the compilation of unified regional and local stratigraphic schemes. The new information obtained under his capable leadership has convinced the vast majority of lake researchers that there is a close relationship between climate, the Earth's orbit (astronomical variations) and the ice age. The obtained data allow correlating lake level fluctuations with climate models. Lake level fluctuations are mostly controlled by climatic changes; however, the tectonic pattern, basin topography, water balance, human activity and several other factors are also of consequence. He showed that in palaeoclimatic reconstructions one has to consider differences in the hydrological regime of lakes in humid and arid environments. 


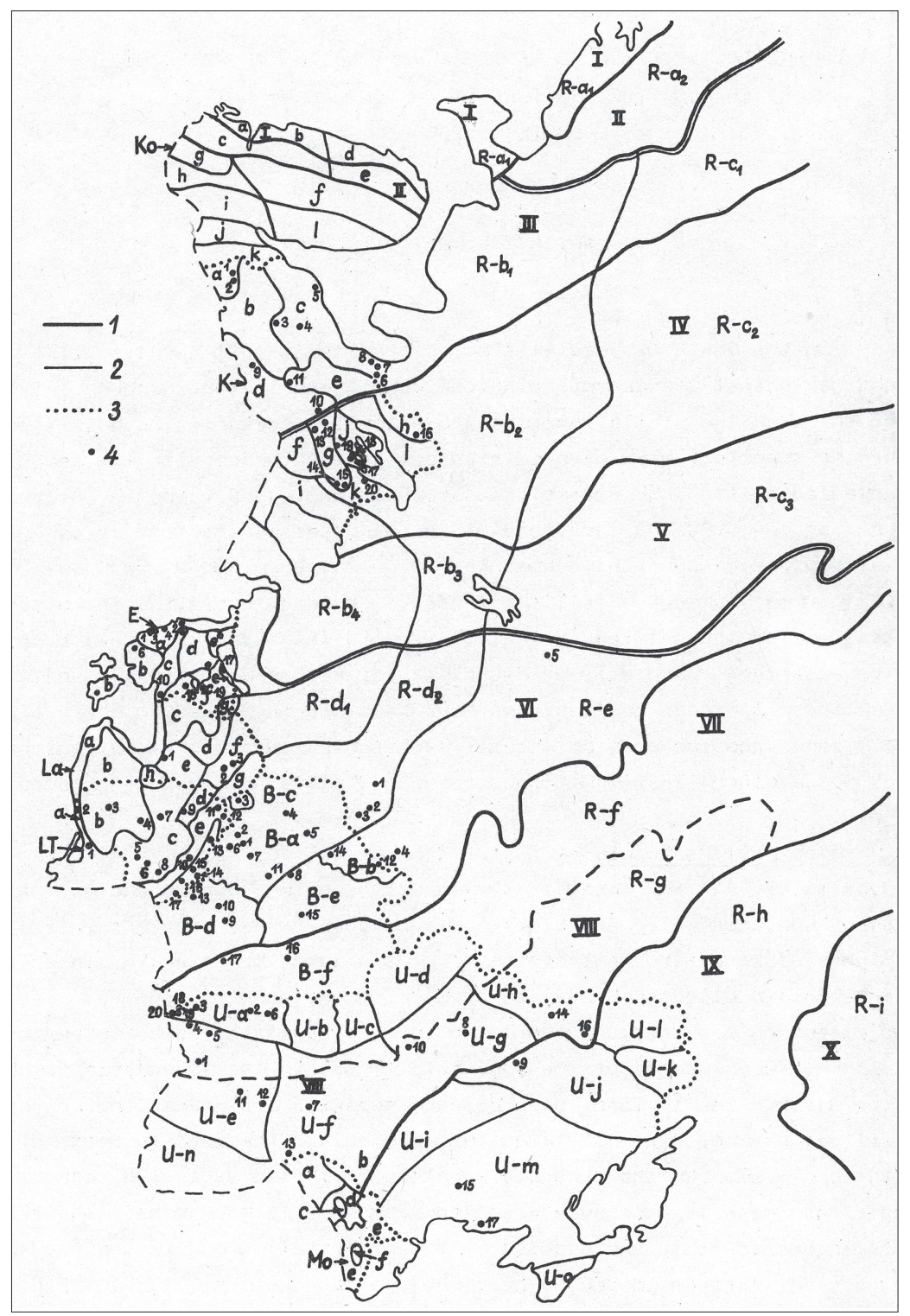

Figure 2. Lake regions and principal reference sites in the European part of the former Soviet Union according to Saarse, Raukas and Kvasov (1987). Boundaries: 1 - between biotic zones, 2 - between natural-geographic regions, 3 - the border of republics and districts (KO - Kola Peninsula; K - Karelia; R - Russia; E - Estonia; La - Latvia; LT - Lithuania; B - Belarus; U - the Ukraine; Mo - Moldova); 4 - reference sites. The zonation in the Russian Federation was given by Dmitri Kvasov. 


\section{Evolution of lakes}

Kvasov demonstrated in his papers that the majority of lakes in the Northern Hemisphere originate in the end of the Pleistocene and the beginning of the Holocene. However, several big lakes in the former Soviet Union, such as Zaisan, Baikal, Issyk-Kul, Chanka, Sevan and several others, are known to have existed in much earlier geological epochs. Research into those lakes would contribute to resolving many topical problems connected with the evolution of the Earth's crust. The flora and fauna existing in the lakes today started to form, for the most part, at the beginning of the Holocene as well. Ancient elements in ecosystems have preserved only in some old lakes, a brilliant example of which is Lake Baikal. That is why Kvasov's main interest was focused on the Late Pleistocene (Kvasov, 1975; 1979; 1987c, a.o.) and even older lakes, well developed in the vast expanses of Russia.

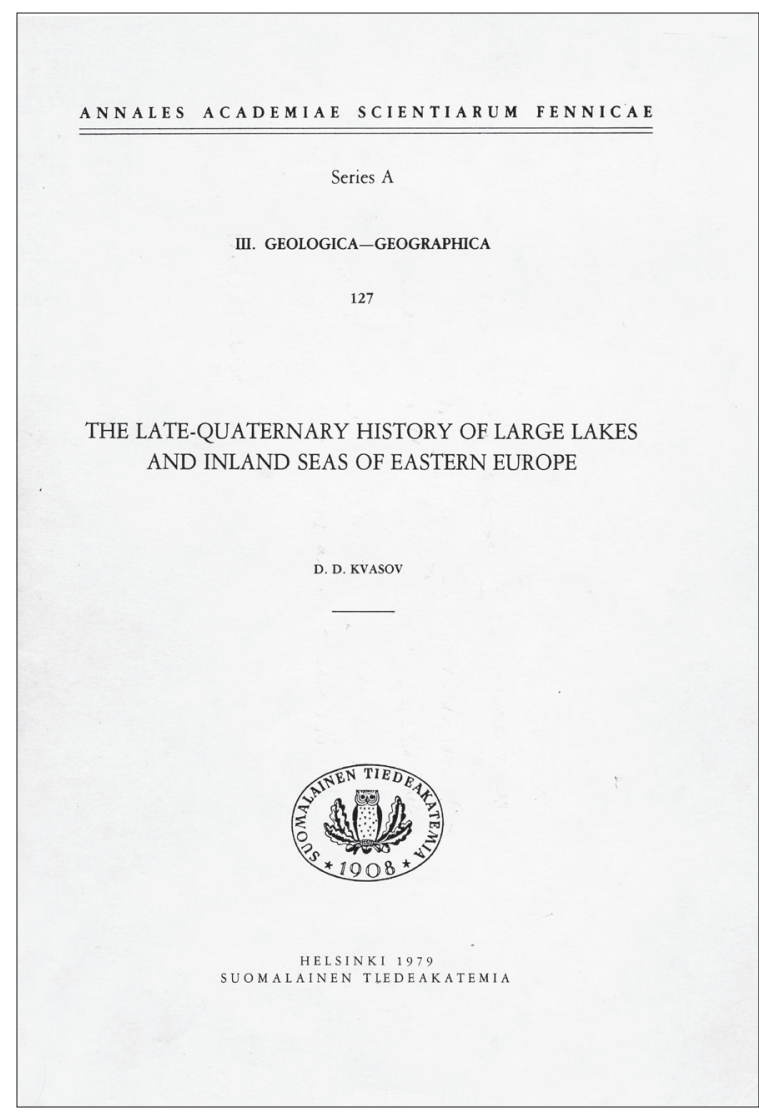

Kvasov's doctoral thesis, which was published in Russian in 1975 (Kvasov, 1975) and later in abbreviated form in English (Kvasov, 1979), was devoted to the LateQuaternary history of the large lakes (ice-dammed lakes, Ladoga, Onega) and inland seas (the Black, Azov, Caspian, White, Baltic), and made it possible to explain the causes of their varied sizes, levels and salinity rates (Fig. 3).

Figure 3. The abbreviated version of Dmitri Kvasov's doctoral thesis, published in Finland (Kvasov, 1979) 
Glacial events have been of great significance in the development of LateQuaternary water bodies in Eastern Europe. According to Kvasov, the maximum of the Weichselian glaciation occurred 17,000-18,000 years BP. The Volga carried glacial meltwater into the Caspian basin, which due to the Khvalynsk transgression was much bigger than today (Fig. 4).

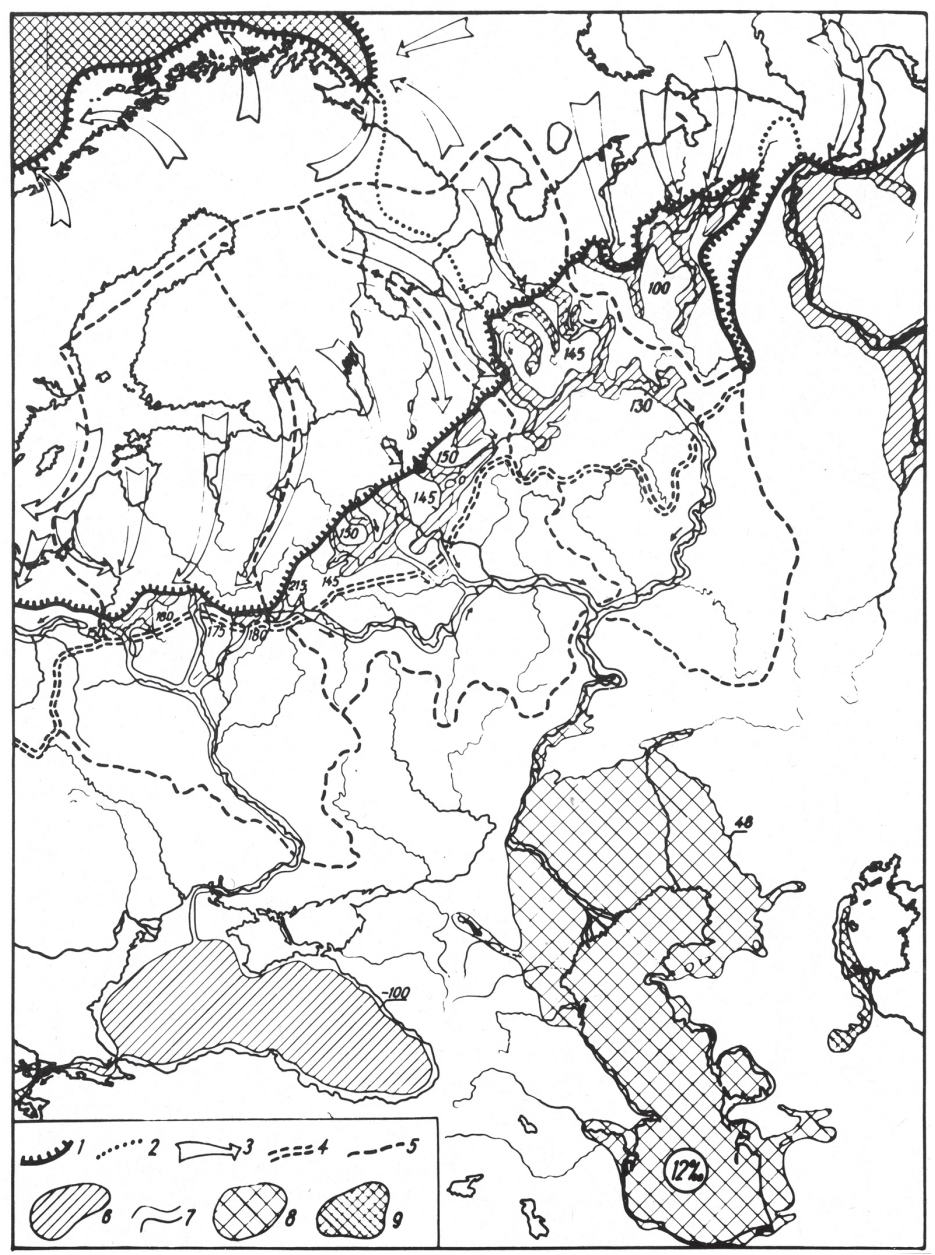

Figure 4. Palaegeographic scheme of the time of the maximum of the last (Weichselian, Valdaian) glaciation (about 17,000-18,000 years BP) according to Kvasov (1979): 1 - the boundary of the glaciation; 2 - the boundary of the ice sheet; 3 - the direction of the glaciers movement; 4 - the main watershed of the East European Plain before the Weichselian glaciation; 5 - the boundaries of the drainage basins, 6 - fresh-water lakes; 7 - valleys through which glacial meltwaters flowed; 8 - low-salinity basins; 9 - high salinity basins. 
Kvasov established that the inflow of glacial meltwater into the Black Sea did not result in a transgression. The level of Lake Euxinus was determined by the level of the runoff threshold in Bosporus and was about 100 metres lower than the present ocean level. Upper-Niemen, Upper-Viliya, Upper-Berezina and Orsha ice-dammed lakes, which drained into the Dniepr basin, existed during the maximum of the Weichselian glaciation. An extensive network of ice-dammed lakes belonging to the drainage basin of the North Dvina and the Mezen drained via the Kama River. An enclosed ice-dammed lobe seems to have existed in the Pechora basin.

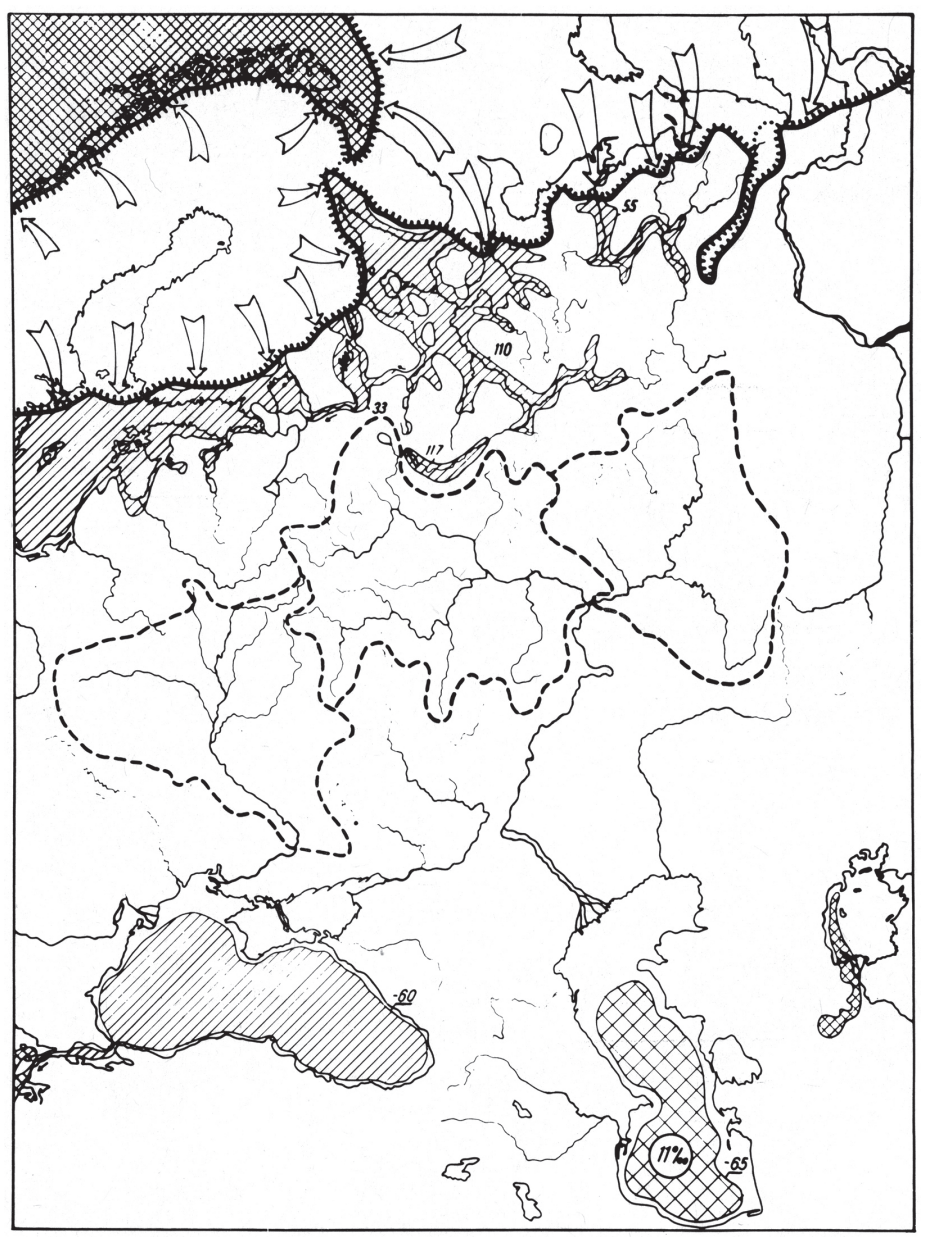

Figure 5. Palaeogeographic scheme in the Late Dryas time (about 10,500-11,000 years BP) according to Kvasov (1979). For the legend see Fig. 4. 
Later on, with the recession of the glaciers the lakes Upper-Niemen and UpperViliya acquired a westward drainage. The retreat of the glaciers from the ice marginal formations of the Vepsa stage (14,500-13,500 years BP) gave rise to a principally new system of ice-dammed lakes. The inflow of glacier meltwater into the Caspian Sea decreased and the level of the Khvalynsk basin dropped to zero $\mathrm{m}$. In the Bölling a corridor was formed between the Scandinavian and the Barents ice sheets which ran through the Dvina and Kandalaksha bays of the White Sea, the western part of Kola Peninsula and the North Cape channel of the Barents Sea. The Pechora and other big northern rivers acquired the northwest drainage.

Step by step, Kvasov painted new palaeohydrological pictures (Fig. 5), proposed a number of new names for the basins (e.g., Lake Ramsay in honour of the great Finnish geologist) or even for lake systems (the Baltic system of ice-dammed lakes). He correlated natural events in Europe with the palaeogeographical changes in West and East Siberia and even in the Far East and Middle Asia. So, he succeeded in demonstrating that during the maximal stages of the Weichselian glaciation Lake Baikal's level dropped and it turned into a closed basin, Lake Balkhash had not yet formed and the water table in Lake Issyk-Kul was $100 \mathrm{~m}$ below present (Kvasov, 1987c).

\section{The multi-volume series}

\section{The History of Lakes in the Soviet Union}

Kvasov made a great contribution to the elaboration of optimal methods for the purposes of palaeoecological and palaeohydrological studies. Through his effort, in 1986, the Institute of Lake Research of the USSR Academy of Sciences published the first volume of the multi-volume series The History of Lakes in the Soviet Union, which was titled The Main Features of the Origin and Evolution of Lakes. Methods of Lake History Investigation (Kvasov et al., 1986). The data on the palaeolimnology of the Late Palaeozoic and Early Mesozoic (Martinson \& Neustruyeva, 1987) and the Late Mesozoic and Cenozoic (Martinson et al., 1988) lakes in the Soviet Union were summarized in the second and third volumes. As already mentioned, in palaeolimnological reconstructions one should take into account the differences in the hydrological regime of lakes in humid and arid environments. According to that, the fourth volume (Kvasov et al., 1990) was a description of the history of big lakes (Ladoga, Onega, Peipsi, 
Baikal and Chanka) in the humid zone of the former Soviet Union, and the fifth volume (Sevastyanov et al., 1991) dealt with great lakes (Sevan, Issyk-Kul, Balkhash, Zaisan, Aral) in the arid zone. The succeeding volumes The History of Lakes of the East-European Plain (Davydova et al., 1992), The History of Lakes of Northern Asia (Davydova et al., 1995) and The History of Pleistocene Lakes of the East-European Plain (Khomutova et al., 1998) were compiled already after the death of Dmitri Kvasov.

\section{Conclusion}

Dmitri Kvasov was a talented scientist with a great power of imagination. He presented original palaeolimnological zonation of the former Soviet Union, gave principally new standpoints on the evolution of lakes in the East European Plain and iniated the publishing of the multi-volume collection about the history of lakes in different humid and arid environments. It is unfortunate that most of his papers and books were published in Russian and have remained unknown to researchers in the West. Without any doubt, Dmitri Kvasov's publications deserve to be used as handbooks by palaeolimnologists all over the world.

\section{References}

Aboltinš, O. P.; Basalykas, A. B.; Voznjačuk, L. N.; Kvasov, D. D.; Krasnov, I. I. \& Raukas, A. V. (1972), 'Die Eisstauseen des Nord-Westens der osteuropäischen Ebene,' Verh. Internat. Verein. Limnol., vol. 18, pp. 1063-1067. https://doi.org/10.1080/03680770.1972.11899577

Davydova, N. N.; Kabailiene, M. V.; Raukas, A. V. \& Yakushko, O. F., eds. (1992), Istoriia ozer Vostochno-Evropeiskoi ravniny [The history of lakes of the East-European Plain], St. Petersburg: Nauka.

Davydova, N. N.; Martinson, G. G. \& Sevastyanov, D. V., eds. (1995), Istoriia ozer Severa Azii [The history of lakes of Northen Asia], St. Petersburg: Nauka.

Khomutova, V. J.; Davydova, N. N.; Raukas, A. V. \& Rumyantsev, V. A., eds. (1998), Istoriia pleistotsenovykh ozer Vostochno-Evropeiskoi ravniny [The history of Pleistocene lakes of the East-European Plain], St. Petersburg: Nauka.

Kvasov, D. D. (1975), Posdnechetvertichnaia istoriia krupnykh ozer i vnutrennikh morei Vostochnoi Evropy [The Late-Quaternary history of large lakes and inland seas of Eastern Europe], Leningrad: Nauka. 
Kvasov, D. D. (1979), The Late-Quaternary History of Large Lakes and Inland Seas of Eastern Europe, Annales Academiae Scientiarum Fennicae, ser. A III, 127, Helsinki: Suomalainen Tiedeakatemia.

Kvasov, D. (1987a), 'The Late Quaternary history of the Volga River,' in A. Raukas \& L. Saarse (eds.) Palaeohydrology of the Temperate Zone, vol. I: Rivers and Lakes, Tallinn: Valgus, pp. 43-55.

Kvasov, D. (1987b), 'Ozernoe raionirovanie Vostochno-Evropeiskoi ravniny (v predelakh RFSFR)' [Lake regions of the East-European Plain of the RSFSR], Proceedings of the Academy of Sciences of the Estonian SSR: Geology, vol. 36, no. 1, pp. 27-35.

Kvasov, D. (1987c), 'Development of northern and central Eurasian lakes in the Late Quaternary,' in A. Raukas \& L. Saarse (eds.) Palaeohydrology of the Temperate Zone, vol. I: Rivers and Lakes, Tallinn: Valgus, pp. 156-168.

Kvasov, D. D.; Davydova, N. N. \& Rumyantsev, V. A., eds. (1986), Istoriia ozer SSSR: Obshchie zakonomernosti vozniknoveniia i razvitiia ozer. Metody izucheniia istorii ozer [The history of lakes in the USSR: Main features of origin and evolution of lakes. Methods of lake history investigations], Leningrad: Nauka.

Kvasov, D. D.; Martinson, G. G. \& Raukas, A. V., eds. (1990), Istoriia ozer SSSR: Istoriia Ladozhskogo, Onezhskogo, Pskovsko-Chudskogo ozer, Baikala i Khanki [The history of lakes in the USSR. The history of Ladoga, Onega, Pskovsko-Chudskoye, Baikal and Chanka], Leningrad: Nauka.

Kvasov, D. D. \& Raukas, A. V. (1970), 'O pozdnelednikovoi istorii Finskogo zaliva,' [On the late-glacial history of the Gulf of Finland], Izvestiia Vsesoiuznogo Geograficheskogo Obshchestva, vol. 102, no. 5, pp. 432-438.

Martinson, G. G. \& Neustruyeva, I. J., eds. (1987), Istoriia ozer SSR: Istoriia ozer pozdnego paleozoia $i$ rannego mezozoia [The history of the lakes in the USSR. The history of Late Palaeozoic and Early Mesozoic lakes], Leningrad: Nauka.

Martinson, G. G.; Neustruyeva, I. J. \& Tolstikova, N. V., eds. (1988). Istoriia ozer SSSR: Istoriia ozer pozdnego mezozoia i kainozoia [The history of lakes in the USSR. The history of Late Mesozoic and Cenozoic lakes], Leningrad: Nauka.

Saarse, L.; Raukas, A. \& Kvasov, D. (1987), 'Preliminary results of the investigation of reference sites and type regions in the European part of the Soviet Union,' in A. Raukas \& L. Saarse (eds.) Palaeohydrology of the Temperate Zone, vol. II: Lakes, Tallinn: Valgus, pp. 9-33.

Sevastyanov, D. V.; Mamedov, E. D. \& Rumyantsev, V. A., eds. (1991), Istoriia ozer SSSR: Istoriia ozer Sevan, Issyk-Kul, Balkhash, Zaisan i Aral [The history of lakes in the USSR. The history of Sevan, Issyk-Kul, Balkhash, Zaisan and Aral], Leningrad: Nauka. 
Anto Raukas, Dr.Sci, professor of geology, honorary doctor of the University of Latvia, Honorary Scientist of Europe and Merited Scientist of the Estonian SSR, honorary member of the World Innovation Foundation, Royal Geographical Society, International Union of Quaternary Research and many other organizations. Senior researcher of Tallinn University and professor emeritus of Tallinn University of Technology. His main scientific interests are glacial geology (Science Award of the Republic in 1996), lake studies (Science Award of the Republic in 2003), history of science (Science Award of the Republic in 1991), meteoritics and environmental problems. Raukas was voted one of the hundred great figures of the 2oth century in Estonia. 